MaPan : Jurnal Matematika dan Pembelajaran

p-ISSN: 2354-6883 ; e-ISSN: 2581-172X

Volume 7 No 1, June 2019 (126-135)

DOI: https://doi.org/10.24252/mapan.2019v7n1a10

\title{
PENGARUH SELF-REGULATED LEARNING TERHADAP KEMAMPUAN REPRESENTASI MATEMATIKA MAHASISWA DALAM PEMBELAJARAN BERBASIS MASALAH
}

\author{
Ifada Novikasari ${ }^{1)}$, Fauzi ${ }^{2)}$ \\ 1,2IAIN Purwokerto \\ 1,2J1. A.Yani, No.40A, Purwokerto, Jawa Tengah \\ E-mail: ifa_da@iainpurwokerto.ac.id ${ }^{1}$, fauzi@gmail.com $^{2}$ )
}

Submitted: 11-11-2018, Revised: 05-03-2019, Accepted: 30-05-2019

\begin{abstract}
Abstrak:
Penelitian ini bertujuan untuk membandingkan dua kelompok dengan perlakuan yang berbeda. Penelitian ini merupakan penelitian eksperimental dengan desain yang digunakan adalah desain perbandingan kelompok utuh. Penelitian ini dibagi menjadi dua kelompok, kelompok pertama diberikan pembelajaran berbasis masalah sebagai kelompok eksperimen dan kelompok kedua sebagai kelompok kontrol menggunakan pembelajaran ekspositori. Populasi dalam penelitian ini sama dengan sampel, yaitu sebanyak 30 mahasiswa tadris matematika yang mengambil mata kuliah geometri analitik. Data dianalisis menggunakan uji Mann Whitney dan Kendall. Hasil penelitian menunjukkan bahwa secara umum kemampuan representasi matematis dari kedua kelompok tidak berbeda secara signifikan, tetapi pada kelompok eksperimen memiliki self-regulated learning lebih baik daripada kelompok kontrol.
\end{abstract}

Kata Kunci: Self-Regulated Learning, Representasi Matematika, Berbasis Masalah, Ekspositori

\section{THE EFFECT OF SELF-REGULATED LEARNING ON STUDENTS 'ABILITY OF MATHEMATICAL REPRESENTATION IN PROBLEM-BASED LEARNING}

\begin{abstract}
:
This research was an experimental study with the design used was the intact-group comparison design. The research class in this design was only one but it was divided into two groups, half of the group was given treatment of problem-based as experimental group and another group using expository learning as control group. The population in this study was the same as the sample, 30 students who took analytical geometry course. Data analysis used Mann Whitney test and Kendall. The results showed that in general the ability of mathematical representation of the two groups did not different significantly, but in the self-regulated learning score the experimental group was better than the control group.
\end{abstract}

Keywords: Self-Regulated Learning, Mathematical Representation, Problem Solving, Expository 
How to Cite: Novikasari, I. \& Fauzi. (2019). Pengaruh self-regulated learning terhadap kemampuan representasi matematika mahasiswa dalam pembelajaran berbasis masalah. MaPan : Jurnal Matematika dan Pembelajaran, 7(1), 126-135.

\section{PENDAHULUAN}

Perkembangan pengetahuan kognitif apabila merujuk dari pendapat Piaget, maka mahasiswa berada pada tahap operasi formal. Pada tahap ini individu yang berusia di atas 11 tahun sudah mengembangkan kemampuan berpikir abstrak. Ciri khas berpikir abstrak adalah berkurangnya penggunaan pengalaman konkret dalam pembelajaran. Kemampuan berpikir yang dikembangkan dalam pembelajaran tersebut menurut Reedal (2010) adalah pengembangan analisis hipotesis dan analisis situasi dalam perspektif yang berbeda. Apabila dikaitkan dengan pembelajaran yang terjadi dalam mata pelajaran eksak, khususnya matematika, pada tahap tersebut mahasiswa akan mengurangi penggunaan media konkret, bahkan ditiadakan. Sehingga tantangan dalam pembelajaran di perguruan tinggi sekarang ini, adalah bagaimana mengembangkan pembelajaran matematika agar dapat dikuasai mahasiswa melalui situasi yang berbeda.

Mahasiswa di program studi Tadris Matematika dibekali dengan mata kuliah matematika dan pembelajaran matematika. Namun masalah muncul ketika mahasiswa di program studi Tadris Matematika kesulitan dalam mata kuliah Geometri Analitik. Berdasarkan observasi yang dilakukan dalam mata kuliah tersebut, peneliti mendapatkan data bahwa mahasiswa kesulitan dalam mengaplikasikan pengetahuan garis dan geometri yang dimiliki. Contohnya, mahasiswa mengalami kesulitan untuk mengubah masalah riil ke dalam bentuk persamaan garis serta kesulitan memberikan pemaknaan atas persamaan garis yang diberikan.

Kesulitan mahasiswa tersebut diidentifikasi sebagai kesulitan dalam membuat representasi matematika dari masalah matematika. Pentingnya representasi diungkapkan oleh Carparo \& Capraro (2006) yang menyatakan bahwa representasi merupakan sesuatu yang penting dalam pembelajaran karena dapat digunakan sebagai arti dari komunikasi dan penalaran seseorang mengenai materi yang dipelajari.

Representasi dalam pembelajaran memiliki pengaruh yang besar pada pemahaman mahasiswa. Hal ini sejalan dengan hasil penelitian yang menunjukkan bahwa semakin banyak representasi yang diberikan dapat 
membantu seseorang untuk berkembang dan menguasai lebih banyak pemahaman (Porzio, 1994) Ada berbagai macam kategori dalam representasi. Nakahara (2008) menggolongkannya ke dalam 5 kelompok, yaitu representasi simbolik, representasi digunakan dalam notasi matematika, seperti bilangan, huruf dan simbol; representasi bahasa, representasi yang digunakan dalam kehidupan sehari-hari; representasi ilustratif, yaitu representasi yang menggunakan ilustrasi, gambar, grafik dan lain-lain; representasi manipulatif, representasi dengan membuat objek tiruan atau model; dan representasi realistik yaitu representasi yang didasarkan pada bentuk nyata objek.

Representasi tidak dapat dipisahkan dari matematika karena merupakan multiple concretizations dari konsep yang dapat mempermudah seseorang dan membuat matematika lebih menarik. Keller \& Hirsch (1998) menyatakan beberapa manfaat yang dapat diperoleh dari penggunaan representasi dalam matematika diantaranya adalah (a) provide multiple concretizations of a concept, (b) selective emphasis and de-emphasis different aspects of complex concepts, and (c) facilitate cognitive linking of representations. Manfaat representasi yang dapat memberikan beragam bentuk konkret dari suatu konsep tersebut mendukung berkembangnya pengetahuan kognitif seseorang.

Representasi berdasarkan beberapa hasil kajian di atas memiliki manfaat besar dalam perkuliahan. Jika mahasiswa mampu memberikan representasi masalah dalam perkuliahan matematika yang diikuti, maka diharapkan dapat mengembangkan pemahaman dan penalaran tentang materi yang dipelajari. Selain hasil belajar tersebut menurut Darr \& Fisher (2004) terdapat faktor afektif yaitu self-regulated learning (SRL) sebagai faktor kunci keberhasilan belajar seseorang. Sebab SRL dapat menuntun seseorang untuk berpikir kritis dan intensif mengevaluasi bagaimana pemikiran, sikap, kebiasaan dan lingkungan bekerja. SRL merupakan bagian dari pengaturan diri ketika menghadapi situasi pembelajaran, Aspek ini diduga berpengaruh pada perkembangan kemampuan representasi matematika mahasiswa.

Merujuk dari Marchis (2011) pembelajaran yang menekankan pada penyelesaian masalah, salah satunya pembelajaran berbasis masalah (PBM) memiliki pengaruh pada pembentukan SRL pembelajar. Self-regulation terkait dengan kegiatan akademik menurut (Zimmerman, Bonner, \& Kovach, 1996) adalah ... refers to self-generated thoughts, feelings, and actions intended to attain specific educational goals, such as analyzing a reading assignment, preparing to take a test, or writing a paper. SRL tersebut berhubungan dengan kemandirian individu sebagai upaya pikiran, perasaan, dan tindakan untuk mencapai tujuan dalam 
pembelajaran, seperti analisis tugas membaca, persiapan tes, tugas menulis makalah, dan sebagainya.

Menurut Levin (2001) pembelajaran berbasis masalah (PBM) sesuai apabila diberikan dalam pembelajaran pendidikan guru. Pendekatan PBM memiliki tujuan untuk memadukan pengetahuan berkaitan dengan masalah serta mengembangkan atau mengaplikasikan keterampilan pemecahan masalah. Pembelajaran yang memuat proses perencanaan, monitoring, pemecahan masalah, dan evaluasi seperti halnya PBM, menurut Perry, VandeKamp, Mercer, \& Nordby (2002) akan memberikan lingkungan belajar yang dapat mengembangkan SRL pembelajar. Ciri perkembangan SRL adalah dalam belajar mahasiswa mengembangkan kesadaran mengenai apa yang dipelajari? Strategi apa yang sesuai? Bagaimana memahami materi? yang dapat diperoleh dari kegiatan refleksi PBM. Tugas Dosen adalah membangkitkan kesadaran tersebut.

Prinsip learner-centered yang terdapat dalam PBM sesuai dengan filosofi konstruktivisme yang diharapkan dapat mempengaruhi SRL mahasiswa dan kemudian mengembangkan kemampuan representasi matematika dalam menyelesaikan masalah yang ada. Mahasiswa secara aktif membangun pengetahuan sesuai kematangan kognitifnya melalui konteks Smith, Dockrell, \& Tomlinson (1997), sehingga mahasiswa menyadari bagaimana ia seharusnya belajar Geometri Analitik. Kesadaran ini bervariasi bagi setiap mahasiswa. Syarat pelaksanaan dalam PBM adalah mahasiswa terlibat aktif dalam pembelajaran berbasis masalah, memungkinkan beragam hipotesis, menggunakan proses penyelidikan untuk mengumpulkan informasi dan mengaitkannya dengan hipotesis, kemudian mendiskusikan solusi masalah berdasarkan hipotesis.

Berdasarkan hasil observasi di atas kesulitan mahasiswa dalam perkuliahan geometri analitik adalah lemah dalam membuat representasi untuk model matematika. Hal ini diduga disebabkan oleh SRL atau kesadaran belajar geometri analitik mahasiswa yang rendah. Maka perlu diupayakan cara berbeda dalam perkuliahan geometri analitik yaitu salah satunya PBM sehingga diharapkan teridentifikasi SRL diduga memiliki pengaruh positif pada kemampuan representasi matematika mahasiswa. Untuk menunjang pembelajaran tersebut akan digunakan pembelajaran berbasis masalah dan pembelajaran ekspositori untuk mengetahui SRL dan kemampuan representasi mahasiswa dalam perkuliahan Geometri Analitik. 


\section{METODE PENELITIAN}

Penelitian ini menggunakan metode penelitian split-half eksperimen (Ziniel, 2008). Kelompok penelitian dalam desain ini hanya satu tetapi dibagi dua, yaitu setengah kelompok diberikan perlakukan pembelajaran geometri analitik berbasis masalah dan setengah untuk kelompok kontrol menggunakan pembelajaran biasa atau ekspositori.

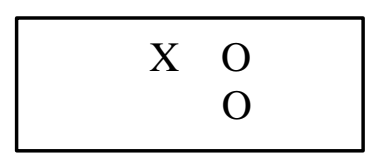

$\mathrm{X}=$ Pembelajaran berbasis masalah

$\mathrm{O}=$ Posttest

Desain di atas menunjukkan bahwa dari satu kelompok kemudian dibagi dua dan kemudian diberikan perlakuan pembelajaran yang berbeda. Setelah mahasiswa mengikuti pembelajaran yang berbeda dosen memberikan posttest pada kelompok tersebut. Dalam pelaksanaannya didapatkan kelompok pertama berjumlah 13 mahasiswa mengikuti perkuliahan matematika menggunakan pembelajaran biasa. Kelompok kedua berjumlah 17 mahasiswa mengikuti perkuliahan dengan pembelajaran berbasis masalah. Perbedaan jumlah tersebut nantinya tidak akan berpengaruh pada analisis data penelitian sebab telah dilakukan uji pengetahuan awal responden. Analisis data lanjutan menggunakan uji Mann Whitney dan Kendall dengan asumsi data tidak harus berdistribusi normal.

\section{HASIL PENELITIAN DAN PEMBAHASAN}

Penelitian ini dilakukan pada satu kelas dengan membaginya menjadi dua kelompok penelitian. Berdasarkan kemampuan matematika sebelumnya, peneliti membagi kelas menjadi dua kelompok yang heterogen. Setelah membagi menjadi dua kelompok, peneliti kemudian melakukan penelitian. Tes kemampuan representasi diberikan setelah proses perkuliahan selesai. Berikut ini hasil tes kemampuan representasi pada kedua kelompok.

Tabel 1. Data Deskriptif Kemampuan Representasi

\begin{tabular}{ccccc}
\hline Kelas & Mean & Std. Deviation & $\begin{array}{c}\text { Std. Eror } \\
\text { Mean }\end{array}$ \\
\hline P. Ekspositori & 3 & 11.92 & 3.818 & 1.059 \\
\hline PBM & 7 & 14.53 & 4.679 & 1.135 \\
\hline
\end{tabular}

Tabel 1 di atas menunjukkan bahwa rata-rata kelas dan standar deviasi kemampuan representasi di kelas pembelajaran ekspositori dan PBM 
menunjukkan perbedaan. Rata-rata kemampuan representasi di kelas pembelajaran biasa menunjukkan nilai 11,92 sedangkan di kelas PBM menunjukkan angka 14,53. Rata-rata kemampuan representasi di kelompok eksperimen lebih tinggi dibandingkan kelompok kontrol. Namun apabila dilihat dari skor standar deviasi menunjukkan bahwa sebaran skor kemampuan representasi di kelompok kontrol lebih homogen dibandingkan dengan skor yang ada di kelompok eksperimen. Ditunjukkan dengan nilai standar deviasi di kelompok pembelajaran biasa lebih kecil dibandingkan di kelompok PBM.

Berdasarkan analisis deskriptif di atas diduga bahwa rata-rata skor kemampuan representasi mahasiswa di kelompok eksperimen yang lebih tinggi dibandingkan kelompok kontrol dapat disebabkan sebaran skor di kelompok eksperimen lebih heterogen. Skor kemampuan representasi matematika mahasiswa yang rendah terbantu oleh skor mahasiswa yang tinggi. Untuk mengetahui ada tidaknya perbedaan secara signifikan maka akan dilakukan uji beda pada kedua kelompok.

Tabel 2. Uji Mann Whitney Kemampuan Representasi

\begin{tabular}{lc}
\hline \multicolumn{1}{c}{ Uji } & Kemampuan Representasi \\
\hline Mann-Whitney U & 77.000 \\
\hline Wilcoxon W & 168.000 \\
\hline$Z$ & -1.436 \\
\hline Asymp. Sig. (2-tailed) & .151 \\
\hline Exact Sig. [2*(1-tailed Sig.)] & $.170^{\mathrm{b}}$ \\
\hline
\end{tabular}

Tabel 2 di atas menunjukkan nilai signifikansi 0,151 atau lebih besar dari 0,05. Artinya bahwa skor kemampuan representasi antara kedua kelompok penelitian menunjukkan tidak adanya perbedaan secara signifikan.

Data mengenai SRL mahasiswa sebagaimana kemampuan representasi, diperoleh setelah perkuliahan selesai. Berikut ini adalah data mengenai SRL mahasiswa.

Tabel 3. Data Deskriptif SRL Mahasiswa

\begin{tabular}{lllccc}
\hline Kelas & N & Mean & $\begin{array}{c}\text { Std. } \\
\text { Deviation }\end{array}$ & $\begin{array}{c}\text { Std. Error } \\
\text { Mean }\end{array}$ \\
\hline \multirow{2}{*}{ SRL } & P.Ekspositori & 13 & 9.15 & 1.463 & .406 \\
\cline { 2 - 6 } & PBM & 17 & 10.24 & 1.522 & .369 \\
\hline
\end{tabular}


Tabel 3 di atas menunjukkan bahwa skor rata-rata SRL di kelompok eksperimen menunjukkan nilai 10,24 lebih tinggi dibandingkan rata-rata di kelompok kontrol yaitu 9,15. Apabila dilihat dari skor standar deviasi menunjukkan nilai yang tidak berbeda jauh. Untuk mengetahui ada tidaknya perbedaan secara signifikan maka akan dilakukan uji beda pada kedua kelompok.

Tabel 4. Uji Mann Whitney SRL

\begin{tabular}{lc}
\hline & SRL \\
\hline Mann-Whitney U & 64.000 \\
\hline Wilcoxon W & 155.000 \\
\hline$Z$ & -1.996 \\
\hline Asymp. Sig. (2-tailed) & .046 \\
\hline Exact Sig. [2*(1-tailed Sig.)] & $.053^{\mathrm{b}}$ \\
\hline
\end{tabular}

Pada tabel 4 di atas menunjukkan nilai signifikansi 0,046 atau lebih kecil dari 0,05. Artinya bahwa skor SRL antara kedua kelompok penelitian menunjukkan adanya perbedaan secara signifikan. Skor SRL kelompok eksperimen menunjukkan nilai yang lebih baik dibandingkan kelompok kontrol. Hal ini ditunjukkan dengan perolehan nilai rata-rata. Selanjutnya akan dianalisis hubungan SRL terhadap kemampuan representasi mahasiswa.

Tabel 5. Korelasi SRL terhadap Kemampuan Representasi

\begin{tabular}{|c|c|c|c|c|}
\hline & & & SRL & Kemp Representasi \\
\hline \multirow{6}{*}{$\begin{array}{l}\text { Kendall's } \\
\text { tau_b }\end{array}$} & \multirow[t]{3}{*}{ SRL } & Correlation & $\begin{array}{r}1.00 \\
0\end{array}$ & $.309^{*}$ \\
\hline & & $\begin{array}{l}\text { Sig. (2- } \\
\text { tailed) }\end{array}$ & · & .035 \\
\hline & & $\mathrm{N}$ & 30 & 30 \\
\hline & \multirow[t]{3}{*}{$\begin{array}{l}\text { KempRepresent } \\
\text { asi }\end{array}$} & $\begin{array}{c}\text { Correlation } \\
\text { Coefficient }\end{array}$ & $\begin{array}{r}.309 \\
*\end{array}$ & 1.000 \\
\hline & & $\begin{array}{c}\text { Sig. (2- } \\
\text { tailed) }\end{array}$ & .035 & \\
\hline & & $\mathrm{N}$ & 30 & 30 \\
\hline
\end{tabular}

*. Correlation is significant at the 0.05 level (2-tailed).

Tabel 5 di atas menunjukkan bahwa pengaruh atau hubungan antara SRL dengan kemampuan representasi matematika mahasiswa di kelompok pembelajaran berbasis masalah menunjukkan nilai 0,309 yang artinya memiliki hubungan yang rendah dan secara signifikan memiliki pengaruh SRL terhadap 
kemampuan representasi matematika mahasiswa pada taraf signifikansi 0,05. Jadi secara umum SRL memiliki hubungan dengan kemampuan representasi namun tingkat hubungannya rendah.

Hasil uji statistik menunjukkan bahwa SRL di kelompok eksperimen secara signifikan lebih baik dibandingkan pada kelompok kontrol. Namun, hasil tes kemampuan representasi matematika menunjukkan tidak adanya perbedaan secara signifikan antara kedua kelompok penelitian. Apabila dianalisis dari latar belakang mahasiswa yang terlibat dalam penelitian ini menunjukkan persentase yang seragam. Bahkan kelompok eksperimen menunjukkan latar belakang sekolah menengah non eksak lebih besar dibandingkan di kelompok kontrol. Meskipun latar belakang selain eksak lebih tinggi dominasinya di kelompok eksperimen dibandingkan kelompok kontrol namun persentase persepsi pemahaman materi yang menganggap "mudah" proses pembelajaran di kelompok eksperimen lebih tinggi dibandingkan kelompok kontrol.

Persepsi dalam proses penyelesaian masalah menunjukkan bahwa mahasiswa di kelompok eksperimen memiliki persentase lebih tinggi pada SRL penyelesaian soal dengan keyakinan penyelesaiannya secara "luar biasa". Alasan yang diberikan mahasiswa karena sudah memahami materi sehingga dapat menyelesaikan soal yang diberikan. Capaian penyelesaian soal di kelompok eksperimen juga memiliki persentase lebih tinggi dibandingkan kelompok kontrol yaitu "sangat bagus".

Dugaan awal penelitian ini, terdapat hubungan SRL terhadap kemampuan representasi matematika mahasiswa. Hasil uji statistik menunjukkan terdapat hubungan meskipun tarafnya rendah antara SRL dengan kemampuan representasi matematika mahasiswa. Sebagaimana menurut Darr \& Fisher (2004) SRL merupakan faktor kunci keberhasilan belajar seseorang. Hasil yang diperoleh dalam penelitian ini memiliki kesamaan dengan temuan Marchis (2011) bahwa pembelajaran yang menekankan pada penyelesaian masalah dalam penelitian ini adalah pembelajaran berbasis masalah (PBM) memiliki pengaruh dalam pembentukan SRL mahasiswa.

Berdasarkan analisis hasil angket menunjukkan sebaran jawaban SRL yang lebih baik kelompok eksperimen dibandingkan kelompok kontrol namun secara umum SRL mahasiswa belum mampu mengembangkan kemampuan representasi matematika. Apabila dianalisis dari hasil tes kemampuan representasi matematika, ditemukan beberapa mahasiswa di kelompok eksperimen sudah mulai berkembang representasi simbolik dan representasi 
ilustratif. Menurut Nakahara (2008) representasi simbolik berupa notasi matematika, seperti bilangan, huruf dan simbol dan representasi ilustartif berupa gambar, grafik, dan sebagainya. Di kelompok kontrol hanya ditemukan 1 orang yang mulai berkembang kemampuan representasinya pada representasi simbolik. Hal ini menyebabkan hubungan SRL yang rendah dengan kemampuan representasi matematika. Namun pengaruh SRL terhadap kemampuan representasi matematika mulai muncul dan lebih baik di kelompok eksperimen yang menggunakan pembelajaran berbasis masalah dengan beragamnya jenis representasi yang muncul.

\section{SIMPULAN}

Hasil analisis statistik kemampuan representasi matematika pada kelompok eksperimen dan kontrol menunjukkan tidak adanya perbedaan secara signifikan. Namun apabila hasil jawaban mahasiswa dianalisis menunjukkan kemampuan representasi matematika kelompok eksperimen berkembang pada representasi simbolik dan ilustratif. Sedangkan di kelompok kontrol kemampuan representasi yang berkembang terbatas. Hasil analisis statistik SRL kedua kelompok menunjukkan perbedaan yang signifikan. Kelompok eksperimen memiliki skor rata-rata SRL yang lebih baik dibandingkan kelompok kontrol. Apabila dianalisis hubungan antara kedua variabel yang diteliti menunjukkan hubungan yang signifikan pada tingkat hubungan yang rendah. Meskipun hubungan yang rendah, kelompok eksperimen lebih baik dalam mengembangkan kemampuan representasi dan SRL.

\section{DAFTAR PUSTAKA}

Carparo, R. M., \& Capraro, M. (2006). Underlying structures of mathematical representation: A theoretical perspective. Paper Presented at the Annual Meeting of the American Educational Research Association. San Francisco, CA.

Darr, C., \& Fisher, J. (2004). Self-regulated learning in mathematics class. selfregulated learning. Conference Paper, 44-49.

Keller, B. A., \& Hirsch, C. R. (1998). Student preferences for representations of functions. International Journal of Mathematics Education in Science and Technology, 29(1), 1-17. Retrieved from https://www.tandfonline.com/doi/abs/10.1080/0020739980290101

Levin, B. (2001). Energizing teacher education and professional development with problem-based learning. Virginia: Association for Supervision and 
Curriculum Development.

Marchis, I. (2011). How mathematics teachers develop their pupils' selfregulated learning skills. Acta Didactica Napocensia, 4(2), 2-3. Retrieved from Acta Didactica Napocensia

Nakahara, T. (2008). Cultivating mathematical thinking trough representation. Retrieved from http://www.criced.tsukuba.ac.jp/math/apec /apec2008/index_en.php.

Perry, N., VandeKamp, K., Mercer, L., \& Nordby, C. (2002). Investigating teacher-student interactions that foster self-regulated learning. Educational Psychologist, 37(1), 5-15. Retrieved from https:/ / psycnet.apa.org/record/2002-12378-001

Porzio, D. T. (1994). The effects of differing technological approaches to calculus on students' use and understanding of multiple representations when solving problems. The Ohio State University.

Reedal, K., E. (2010). Jean Piaget's cognitive development theory in mathematics education. Retrieved from http:/ / ripon.edu/ macs/summation

Smith, L., Dockrell, J., \& Tomlinson, P. (1997). Piaget, Vygotsky and Beyond. London: Routledge.

Zimmerman, B., Bonner, S., \& Kovach, R. (1996). Developing self-regulated learners: Beyond achievement to self efficacy. Washington: American Psychological Association.

Ziniel, S. (2008). Split-half. Encyclopedia of Survey Research Methods. 